\title{
The knowledge spillover theory of entrepreneurship: an application to foreign direct investment
}

\author{
Zoltan J. Acs* \\ School of Public Policy, \\ George Mason University, \\ 3401 Fairfax drive, Virginia, USA \\ E-mail: zacs@gmu.edu \\ *Corresponding author

\section{David J. Brooksbank} \\ Cardiff School of Management, \\ University of Wales Institute Cardiff, \\ Western Avenue, Cardiff, CF5 2YB, UK \\ Fax: +44-29-2041-6930 \\ E-mail: Dbrooksbank@cardiffmet.ac.uk
}

\section{Colm O'Gorman}

DCU Business School,

Dublin City University,

Dublin 9, Ireland

E-mail: colm.ogorman@DCU.ie

\section{David Pickernell}

Centre for Enterprise, Business School,

University of Glamorgan,

Pontypridd, CF37 1DL, Wales, UK

Fax: +441443483560

E-mail: dgpicker@glam.ac.uk

\section{Siri Terjesen}

Department of Management and Entrepreneurship,

Kelley School of Business,

Indiana University,

1309 E. 10th St., Bloomington, Indiana 47405, USA

Fax: +1-812-855-4246

E-mail: terjesen@indiana.edu 


\begin{abstract}
Does the knowledge spillover theory of entrepreneurship provide an explanation for the emergence of knowledge-based entrepreneurship in Ireland and Wales? To examine the reasons for different levels of knowledge-based entrepreneurship in these two regions we explore FDI and entrepreneurship policy. We outline key measures of knowledge creation, and evaluate the extent and nature of FDI activity and its relationship with entrepreneurship in general and knowledge-based entrepreneurship in particular. Policy implications include the need for more integrated policy directions for countries that are characterised by weak knowledge creating institutions yet wish to encourage knowledge-based entrepreneurship.
\end{abstract}

Keywords: entrepreneurship; knowledge spillovers; foreign direct investment; Ireland; Wales.

Reference to this paper should be made as follows: Acs, Z.J., Brooksbank, D.J., O'Gorman, C., Pickernell, D. and Terjesen, S. (2012) 'The knowledge spillover theory of entrepreneurship: an application to foreign direct investment', Int. J. Entrepreneurship and Small Business, Vol. 15, No. 2, pp.237-261.

Biographical notes: Zoltan J. Acs is a University Professor at the School of Public Policy and Director of the Center for Entrepreneurship and Public Policy at George Mason University. He is a co-editor and Founder of Small Business Economics. He has served as a Research Fellow at the US Bureau of the Census and Chief Economic Advisor at the US Small Business Administration (SBA). He completed his undergraduate at Cleveland State University and his MA and doctorate at the New School. Together with David Audretsch, he received the 2001 International Award for Entrepreneurship and Small Business Research. He has published more than 100 articles and 20 books, including articles in the American Economic Review, Review of Economics and Statistics, Kyklos, Journal of Urban Economics, Economica, Research Policy and Science Policy.

David Brooksbank is currently Professor and Director of Enterprise at the Cardiff School of Management, University of Wales Institute Cardiff in the UK. He has published research in the areas of entrepreneurship and the link with regional economic development, applied labour economics and the measurement of entrepreneurial activity. His current research involves innovation and small firm development in Wales and comparisons with international benchmarks on enterprise. His commercial consultancy work has included work on the production of national enterprise policies, as well as economic development strategies for local and national agencies. He has also been successful in attracting funding for numerous European Union projects focused on developing a better understanding of enterprise and entrepreneurship, as well as a portfolio of undergraduate and Masters level qualifications in entrepreneurship.

David Pickernell is the co-Director of the Centre for Enterprise and Professor of Economic Development Policy at the University of Glamorgan Business School. He is also an Adjunct Professor in the School of Management at Queensland University of Technology in Brisbane Australia. His research interests encompass foreign direct investment and local-global interactions, clusters and networks, regional economic development policy, construction, entrepreneurship, universities and economic development, innovation, social enterprise and social capital building. He has had over 50 articles published in refereed journals, given over 30 conference papers and had a number of chapters in edited books. He has also undertaken research and consultancy for a 
range of organisations, including the OECD, EU, Welsh Assembly Government, Queensland Government, Victorian Government (Australia), Welsh Development Agency, Cardiff Council, Council of Mortgage Lenders, Associated British Ports, Shaw Trust, and the Federation of Small Businesses.

Colm O'Gorman is Professor of Entrepreneurship and Associate Dean for Research at Dublin City University Business School in Ireland. $\mathrm{He}$ has published papers in international peer-reviewed journals on topics such as the growth strategies of SMEs, the nature of managerial work in high growth SMEs, mission statements in SMEs, and internationalisation processes in INVs and in SMEs. He is the co-author of a text book on entrepreneurship for Irish students and he has written teaching cases studies on entrepreneurship, several of which are award winning. His current research focuses on the role of entrepreneurship in the emergence of new industries; the strategic attributes of high growth firms; and the extent and nature of entrepreneurial activity in Ireland.

Siri Terjesen is an Assistant Professor of Management and Entrepreneurship in the Kelley School of Business at Indiana University. Her research is published in leading journals such as Strategic Management Journal, Journal of Operations Management, Small Business Economics, Entrepreneurship Theory $\&$ Practice, Strategic Entrepreneurship Journal, and Venture Capital. She is the co-author of the textbook, Strategic Management: Thought and Action. Her research has been profiled in US News \& World Report, Christian Science Monitor, Voice of America, Entrepreneur.com, Management Issues, Times, $C N B C$ Europe and other outlets. She received her BS from the University of Richmond, MSc from Norges Handelhøyskole (Norwegian School of Economics and Business Administration), and $\mathrm{PhD}$ from Cranfield University. She undertook a post-doctoral fellowship at the Queensland University of Technology in Brisbane, Australia.

\section{Introduction}

The field of international entrepreneurship is concerned with "actors (organizations, groups, or individuals) who discover, enact, evaluate, or exploit opportunities to create future goods or services and who cross national borders" as well as comparisons of "domestic entrepreneurial systems, culture and behaviors across national borders" [Oviatt and McDougall, (2005), p.540]. Thus, international entrepreneurship has two subfields: internationalisation (e.g., Kraus, 2011) and comparative international studies (Terjesen et al., 2011). The present study is concerned with the other subfield of comparative international entrepreneurship in the context of Ireland and Wales. In particular, we ask if government policies can lead to increased levels of knowledge intensive entrepreneurship.

In seeking to influence levels of knowledge intensive entrepreneurial activity, policymakers face two significant problems. First, to effectively influence the scale and scope of entrepreneurial activity, policymakers need to understand 'what determines the supply of productive entrepreneurship' [Baumol, (1993), p.16] or, phrased differently, what factors influence a country's 'entrepreneurial capital', defined as the 'regional milieu of agents that is conducive to the creation of new firms' [Audretsch and Keilbach, (2004), p.420]. Clearly not all national economic systems are equally good at supporting 
entrepreneurship or new market entry as evidenced by variations in the levels of entrepreneurial activity across national context (Acs et al., 2004; Audretsch et al., 2002; Scarpetta, 2003), within national contexts (Johnson, 2004; Reynolds et al., 1994), and over time (Carree et al., 2002; Chandler, 1990). Policy choices made at national and regional levels give rise to the evolution of differing institutional arrangements between countries and within countries. Providing direct and indisputable evidence of the relationship between any given institutional arrangements and entrepreneurial activity is a 'difficult and perhaps an impossible task' [Davidsson and Henrekson, (2002), p.99; Autio and Acs, 2010]. As such there is still ambiguity about which aspects of context explain variation in entrepreneurial activity generally, and knowledge intensive entrepreneurship in particular, and therefore, what policies might be appropriate to encouraging more entrepreneurial activity (Storey, 2000).

A second problem faced by policymakers is that, even if the appropriate set of conditions for increased entrepreneurial activity are identified, it may not be clear how best to influence the environment to cause an increase in the supply of entrepreneurs. Baumol (1993, p.17) suggests that many of the factors that affect the supply of entrepreneurial activity may be difficult to influence, as the process of change is 'slow and undependable'. For example, in countries where a collectivistic, high uncertainty avoidance culture is seen as an inhibitor of entrepreneurial activity, a policy intervention in the education system may be appropriate (Mueller and Thomas, 2001). However, a long period of time may need to elapse before an education initiative might be expected to impact on levels of entrepreneurial activity. Similarly, if low levels of entrepreneurial activity reflect current industry structure, as Davidsson and Henrekson (2002) argue is the case in Sweden, how does the policymaker influence a country's industrial structure?

The knowledge spillover theory of entrepreneurship provides a parsimonious explanation for the emergence of knowledge intensive entrepreneurial activity by relating entrepreneurship to the presence or absence of knowledge creating institutions and to the factors that might impede knowledge spillovers from such organisations (Braunerhjelm et al., 2010). According to the knowledge spillover theory of entrepreneurship, levels of knowledge-based entrepreneurship relate to two factors: the extent to which private firms and public institutions generate new knowledge; and the extent to which individuals exploit that new knowledge. Therefore we expect that the absence of domestic knowledge creating institutions, such as public research institutes, and/or the absence of a sufficiently scaled indigenous industry base might militate against the emergence of knowledge-based entrepreneurship. Indeed, Audretsch and Keilbach (2007) demonstrate that there are lower levels of knowledge-based entrepreneurship in German regions characterised by a lower percentage of the work force accounted for by scientists and engineers. We also expect that levels of knowledge-based entrepreneurship will be absent where individuals fail to commercialise new knowledge via entrepreneurship. Individuals with new knowledge might under invest in commercialisation activity as they do not see the benefits, or fail in their attempts to commercialise, due to a lack of market knowledge; and those individuals or organisations with market knowledge or other resources may not be aware of the new knowledge, and therefore fail to invest, or under invest, in the knowledge or in new firms (Braunerhjelm et al., 2010).

In the absence of domestic knowledge creating capacity policymakers in open economies might seek to access spillovers from across their geographical borders either indirectly or via the attraction of inward foreign direct investment (FDI). However, for many policymakers, accessing knowledge spillovers from inward FDI has proved to be 
an elusive policy objective. Blomstrom and Kokko (2003), for example, argue that investment incentives that attract inward FDI do not necessarily promote spillovers of foreign technology and skills to local industry, with such benefits only actually occurring if local firms also have the ability and motivation to invest in absorbing foreign technologies and skills. This suggests that for spillover benefits to accrue to the local economy, policies aimed at attracting FDI need to be accompanied by policies which support learning and investment by local firms, as well as broader entrepreneurship policies.

In a previous paper, Acs et al. (2007) examined the relationship between entrepreneurship and FDI in developed and developing countries. The purpose of this paper is to extend this research to examine if the knowledge spillover theory of entrepreneurship applied to FDI can provide an explanation, or at least part of it, for differences in the levels of knowledge-based entrepreneurship in the two developed regions of Wales and Ireland, both of which have undergone major economic restructuring in recent years.

The knowledge spillover theory of entrepreneurship provides us with a theoretical explanation of how FDI can result in knowledge-based entrepreneurship. In this paper, we use this theory to examine FDI and entrepreneurship policy choices in two case study regions and to explore how these policies may have impacted on levels of knowledge-based entrepreneurship. The paper is organised as follows. First, we briefly articulate why the knowledge spillover theory of entrepreneurship might explain variations in the levels of knowledge -based entrepreneurship both generally, and more specifically as this relates to FDI. This is followed by a description of our data sources and a rationale for the choice of Ireland and Wales as our cases in terms of location, similar indigenous knowledge creation experiences and dissimilar economic growth trajectories. We then present our case study data for Ireland and Wales. For the two cases we present:

1 inward FDI

2 entrepreneurship outcomes, including a comparison of entrepreneurs in general and exploring the profile of knowledge-based entrepreneurs in particular

3 public policies focused on attracting FDI and encouraging entrepreneurship.

The next section compares Ireland and Wales and highlights how policies may have influenced the extent of knowledge spillovers from FDI leading to knowledge-based entrepreneurship. We then discuss how the knowledge spillover theory of entrepreneurship, as applied to FDI, provides an explanation of the higher levels of knowledge-based entrepreneurship in Ireland. We conclude with possible policy directions for countries that are characterised by weak knowledge creating institutions but wish to encourage knowledge-based entrepreneurship.

\section{The knowledge spillover theory of entrepreneurship and its relationship with FDI}

The knowledge spillover theory of entrepreneurship relaxes two central (and unrealistic) assumptions of Romer's (1990) endogenous growth model. The first is that knowledge is automatically equated with economic knowledge. In fact as Arrow (1962) emphasised, 
knowledge is inherently different from the traditional factors of production, resulting in a gap between knowledge $(K)$ and what he termed economic knowledge $\left(K^{c}\right)$. The second involves the assumed spillover of knowledge. The existence of the factor of knowledge is equated with its automatic spillover, yielding endogenous growth. In the knowledge spillover theory of entrepreneurship, institutions impose a gap between new knowledge and economic knowledge $\left(0<K^{c} / K<1\right)$ which results in a lower level of knowledge spillovers (Acemoglu et al., 2004). Based on this simple model originating in standard assumptions applied in microeconomics, an increase in the stock of knowledge should have a positive effect on the degree of entrepreneurship. The extent of the impact is however likely to be determined by the efficiency of incumbents to exploit knowledge: the more efficient incumbents are, the smaller the effect of new knowledge on entrepreneurship. Second entrepreneurial activities are also likely to be lower in contexts or situations of higher regulations or inefficient or inappropriate governmental intervention.

Audretsch and Lehmann (2005) used the knowledge spillover theory of entrepreneurship to study the role of universities (and their knowledge output) and the knowledge capacity of regions in promoting entrepreneurial activity. Could the theory also be applied to the emergence of knowledge intensive entrepreneurship in regions characterised by policies aimed at attracting inward FDI?

Inward FDI may be important to knowledge-based entrepreneurship for a number of reasons. First, firms are interested in operating in countries in which they can take advantage of strategic assets, especially intangibles such as information and human capital. Internalisation theory describes how local firms' knowledge of laws and relationships with local players provide 'home court advantages'. Foreign firms must therefore leverage special advantages, often information -based intangibles, in order to compete in these markets (Morck and Yeung, 1992). FDI therefore has the ability to transfer productivity raising, often tacit knowledge into a region from companies involved in global competition (see Liu, 2002; Saliola and Zanfei, 2009), making them more likely to embody the latest technology and be more valuable than purely domestic $\mathrm{R} \& \mathrm{D}$, which is also more likely to lag in its commercial ability.

Second, during the course of these FDI activities, there is a transfer of technology and intangibles to the host country that involves people and machinery, and some of this knowledge spills over. These spillovers are not necessarily intentional, given that the MNE is a profit maximising entity and is not willing to transfer knowledge unless it obtains a return. Knowledge spillovers often, however, result from a gap in technology between foreign and local firms, the amount of intangible spillovers increasing with the presence of MNEs and the size of the foreign local firm technology gap. MNE activities which are more knowledge intensive (e.g., R\&D) will receive more knowledge. Also, if the foreign unit of the MNE competes with local firms then the MNE may inject more support in the form of knowledge transfer. Such knowledge spillovers can then lead to the establishment of new home grown enterprises in the host country, leading to further economic development (Young et al., 1994).

Third, beneficial resource transfers can take the form of importation of capital and technology, but also the diffusion of skills and techniques (Munday, 1995). The most obvious conduit for diffusion of this knowledge is via buyer supplier relations to SMEs in the supply chain (Pickernell, 1997). Alternative resource transfer could also, however, occur via the labour market, directly via those who previously worked in multinational 
companies in the region, as well as via physical proximity giving the opportunity for visits and benchmarking (Pickernell, 1999).

Finally, where there is a concentration of FDI located in a region, but there is a lack of local 'embeddedness' because of weak local supply chains linkages or a lack of higher level functions (Munday, 1995) then this can have a deleterious effects on SME development and knowledge-based entrepreneurship in particular, because the shortage of higher level jobs forces potential employees to leave a region, reducing the pool of potential entrepreneurs and innovators (Firn, 1975). This can be seen as being linked to both reasons for low levels of knowledge -based entrepreneurship, in that the FDI may not transfer knowledge because of poor conduits for doing so, but may also exacerbate the problem of the region lacking those with the requisite skills to exploit the knowledge that does spill over.

In this paper we propose that the knowledge spillover theory of entrepreneurship, as applied to FDI, suggests that knowledge intensive FDI can lead to knowledge spillovers, and subsequently increased levels of knowledge-based entrepreneurship, but the extent and nature of FDI will influence the degree to which new knowledge is developed and therefore the extent to which knowledge intensive opportunities will emerge. For beneficial (to the region) knowledge spillovers to occur from FDI, we propose that it is also likely that public policies in the areas of FDI and entrepreneurship must specifically seek to promote and exploit such spillovers if they are to maximise the benefit of such FDI. We explore the theory's applicability in the contexts of Ireland and Wales.

\section{Research method}

To examine the relationship between FDI, knowledge-based entrepreneurship, and public policies we present data from two cases: Ireland and Wales. While these contexts differ in terms of political status and industrial development trajectories, we argue that they offer a 'natural experiment' for exploring the impact of policy on the relationship between FDI and knowledge-based entrepreneurship. The comparison of Ireland and Hungary by Acs et al. (2007) illustrates the potential usefulness of this approach.

Ireland and Wales are both relatively small, peripheral economies (a population of approximately 4.5 million in Ireland, and 3 million in Wales). Ireland is an independent sovereign state, while Wales is a quasi autonomous nation within the UK. This creates different policy constraints and policy options. For example, Ireland was able to secure direct EU funding, while in Wales access to EU funding is dependent on UK central government decisions.

While the two cases are characterised by different historical industrial development trajectories, Ireland and Wales both lacked indigenous knowledge creating capacity. Both Ireland and Wales spend only around $1.1 \%$ of their GDP on R\&D, compared with an OECD average of $2.25 \%$ (OECD, 2006a) (Table 1). Therefore, we might expect that knowledge intensive entrepreneurship will be dependent either on spillovers from FDI or from spillovers from other neighbouring regions. Whilst knowledge spillovers could also spread indirectly across the borders of these very small open economies, their geographical proximity and similar lack of strong indigenous 
absorptive knowledge capacity in the past [as evidenced by the OECD (2006a) R\&D data] suggest that they would have similar experiences of this method of knowledge spillover. This leads us to expect that FDI may be an important source of new knowledge in these regions.

Table 1 R\&D as a percentage of GDP, 1982 to 2004

\begin{tabular}{lccccc}
\hline Year & Ireland & Wales & UK & EU15 & OECD \\
\hline 1982 & 0.67 & & & & 2.01 \\
1984 & 0.71 & & & 1.75 & 2.12 \\
1986 & 0.83 & & 2.26 & 1.86 & 2.23 \\
1988 & 0.80 & & 2.14 & 1.89 & 2.22 \\
1990 & 0.83 & & 2.15 & 1.92 & 2.27 \\
1992 & 1.04 & & 2.03 & 1.85 & 2.16 \\
1994 & 1.27 & 0.5 & 2.01 & 1.80 & 2.06 \\
1996 & 1.32 & 0.9 & 1.88 & 1.78 & 2.10 \\
1998 & 1.25 & 0.9 & 1.80 & 1.79 & 2.15 \\
2000 & 1.14 & 1.1 & 1.86 & 1.87 & 2.23 \\
2002 & 1.12 & 1.0 & 1.89 & 1.91 & 2.24 \\
2004 & 1.21 & 1.3 & & & \\
\hline
\end{tabular}

Source: OECD (2006b); Regional Trends (various years)

Despite both having many years' experience of policies aimed at attracting inward FDI, Ireland and Wales differ significantly in terms of economic performance, with Ireland experiencing rapid economic development during the period of 2000 to 2008, whilst Wales' relative GDP per head has dropped steadily over the last 20 years.

In order to explore some of the possible reasons for these differences as they relate to knowledge-based spillovers, we compare and contrast Ireland and Wales in terms of the extent and nature of FDI (1980 to 2006); the extent of knowledge-based entrepreneurship (2003 to 2006); and the characteristics of entrepreneurs (2003 to 2006). We then review the emergence of FDI policies and entrepreneurship policies aimed at exploiting spillovers from FDI in both Ireland and Wales. We use secondary data sources to describe the extent of knowledge creating institutions in Ireland and Wales, the nature of FDI activity, and the policies pursued around FDI and knowledge intensive entrepreneurship. We use global entrepreneurship monitor (GEM) data to estimate the levels of knowledge-based entrepreneurship in Ireland and Wales and make a comparison by sector, age, sex, education level, export and growth focus. GEM survey data is drawn from population samples for 2003 to 2006 in Wales and Ireland estimating the prevalence rates of early stage entrepreneurship1. A standardised telephone survey was conducted of a representative sample of adults, including 6,779 in Ireland and 20,121 in Wales. The survey provides a broad array of information related to individuals' demographics, perceptions of the country environment for entrepreneurship, attitudes and awareness of entrepreneurship and the self reporting of involvement in entrepreneurial activities (see, Reynolds et al. (2005) and Levie and Autio (2008) for reviews of the GEM methodology). 


\section{Case data: FDI, entrepreneurship and policy in Ireland and Wales}

\subsection{FDI in Ireland and Wales}

Both Ireland and Wales have been relatively successful in attracting inward FDI over the past several decades. FDI inflows in Ireland and Wales for the period 1993 to 2002, for example, were US\$97.2 billion and US\$38.8 billion respectively. The Welsh figure represents approximately $8 \%$ of inflows into the UK. Relative to OECD countries, this places Ireland 12th of 30 countries. While the UK ranks third, inflows into Wales would rank Wales as 20th. However, there are important differences between Ireland and Wales in terms of recent general economic performance. After 1997, for example, FDI inflows to Ireland increased significantly while in Wales, FDI inflows declined (Jones and Wren, 2002; Cooke, 2003).

Since the 1970s there has been a significant change in the sectors represented by foreign firms located in Ireland (Figure 1). Within manufacturing activities there has been a shift away from low tech sectors and towards high tech sectors, especially since the early 1970 s. In $1974,65 \%$ of employment in foreign firms was in low tech sectors, $23 \%$ in medium tech sectors and $12 \%$ in high tech sectors. By 1999 , low tech had declined to $24 \%$, medium tech had declined to $20 \%$ and high tech had increased from $12 \%$ to $56 \%$. So by the end of the 1990s, over half of all foreign industry was in high tech sectors (office and computing machinery; professional instruments; pharmaceuticals; communications equipment; electrical apparatus; and aircraft), with about a quarter in each of medium tech and low tech sectors.

Figure 1 Manufacturing FDI in Ireland by sector, 1974 to 1999

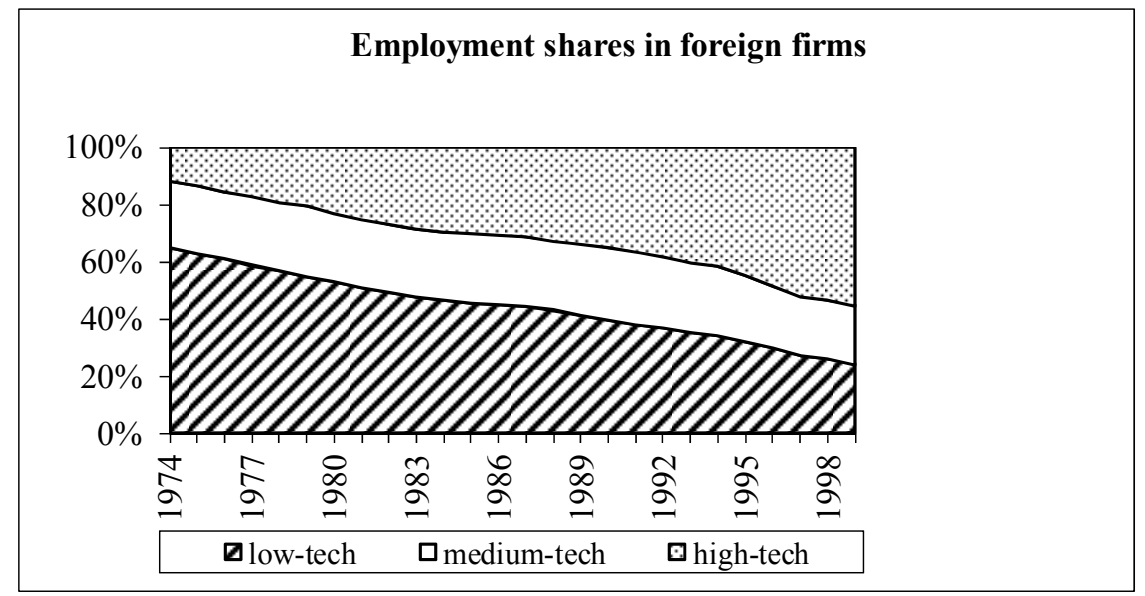

Source: Naveretti and Venables (2004)

In addition to a shift from low technology to high tech manufacturing activities, there was an increase in the importance of the internationally traded service sectors in Ireland during the 1990s. Employment in internationally traded services sectors (by Irish and foreign owned firms) increased from just under 16,000 in 1993 to just over 68,000 in 2000 , an increase of $23.3 \%$ p.a. (in the same period manufacturing employment grew from 219,000 to 281,000 , or $3.6 \%$ p.a.) (National Economic and Social Research 
Council, 2003). The direct contribution of foreign owned multinationals in the internationally trading sectors accounted for approximately $16 \%$ of total employment growth for this period. In Ireland in 2004, there were slightly over one thousand international corporations employing 129,000 staff. Annual output for 2002 from foreign owned companies amounted to $€ 69 \mathrm{~B}$, of which $€ 65 \mathrm{~B}$ (or nearly $95 \%$ ) was exported. Of the one thousand foreign firms with some operations in Ireland, 46\% were headquartered in the USA and accounted for $75 \%$ of all exports from foreign owned Irish subsidiaries and $69 \%$ of employment in foreign owned Irish subsidiaries 2 .

Wales, with just $5 \%$ of the UK population, has also attracted a disproportionate percentage of (UK bound) FDI. Jones and Wren's (2002) data suggests, however, that this rate fell over the 1990 s from nearly $13 \%$ in 1989 to $6.1 \%$ in 1999 . Approximately $40 \%$ of the foreign investors that were supported with UK government financial aid in the 1990s were from the USA, followed by significant inward investment from the rest of Europe and Japan (Brooksbank and Pickernell, 2001; Phelps et al., 2003) [see Brooksbank and Pickernell (2001) for more details on the regional selective assistance (RSA) discretionary grants, which were aimed at creating or safeguarding employment]. In terms of direct employment, the Welsh Office (1997) indicated that foreign firms employed around 75,000 in manufacturing, over a third of the total manufacturing workforce.

The two countries also differ in terms of the nature of FDI (Table 4). Sectors with higher levels of FDI in Ireland compared to Wales include chemicals, machinery and equipment, and services generally, with a clear concentration in Ireland on transport, communications and financial services.

Sectors where inward FDI is more important in Wales than in Ireland include timber based industries, electronics and motor vehicles. In Wales, there is a concentration of FDI in electronics (39.6\%), as well as automotive and transport equipment (15.7\%). There are also relatively large amounts of Welsh grant aid focused on the automotive component and electronics sectors (these sectors account for $43 \%$ of all employment in foreign firms). However, it could be argued that, very broadly, both countries have enjoyed significant FDI in 'knowledge based' sectors, such as chemicals, machinery, electronics, transport equipment and business services (67.8\% in Ireland versus $70.8 \%$ in Wales). Plants in 'high technology' SIC sectors can, however, also feature low levels of skills, and low functionality, due to the ability of multinationals to spatially separate assembly from higher level functions such as R\&D (Pickernell, 1999). In Ireland several studies suggest that there is FDI in some sectors in Ireland that is increasingly embedded. For example, in the ICT sector Amin and Tomaney (1998) found that there are examples of plants occupying a relatively strategic position within the corporation. Coe (1997) argues that overseas firms in the ICT sector are relatively weakly embedded; though he also highlights how more recent inward FDI in the sector is of a higher quality than earlier investments. Coe also describes how the higher quality of FDI is evidenced by "the strategic role of Irish plants within the networks of multinationals... and the attraction of new functions to plants once they have become established" [Coe, (1997), p.227].

In contrast Wales has a relative paucity of higher level functions such as R\&D in industries populated by foreign firms. Roberts (1996) finds in Wales almost $77 \%$ of employees in foreign firms were operatives or assembly workers, compared to the UK FDI average of $60 \%$ (CSO, 1992). Given that $48 \%$ of the Welsh workforce were in manual occupations at the time when FDI was at its height (Regional Trends, 1996), it is clear that FDI in Wales was not relatively concentrated in the higher paid non-manual 
occupations as a result of FDI. Morgan (1991) also concludes that Wales was particularly afflicted by the 'branch plant' economy model in electronics due to the lack of R\&D carried out by inward investors in Wales.

Multinationals based in Wales were able to spatially separate assembly from higher level functions such as R\&D. Furthermore, there are relatively low levels of R\&D activity among foreign firms in Wales. For example, in terms of the automotive component sector, Clifton et al.'s (2000) survey of Welsh first tier automotive suppliers reported that $23 \%$ of UK firms, and $40 \%$ of non-UK firms do not locate R\&D activities in Wales. Another study reports that $52 \%$ of firms conduct some research, design and development activity on site, though the predominant focus is routine activities such as product testing and adaptation (Phelps et al., 2003). Higher level R\&D tends to emerge from the parent company or other international sources, with only $2 \%$ to $4 \%$ developed with local linkages (e.g., universities, research institutions, innovative SMEs) (Phelps et al., 2003).

\subsection{Entrepreneurship in Ireland and Wales}

GEM data from 2003 to 2006 indicates clear differences in terms of both the levels and nature of entrepreneurial activity generally and specifically those related to knowledge-based activities between Ireland and Wales. Using GEM defined variables, Total Early Stage Entrepreneurial Activity (nascent entrepreneurs plus those that have started a new firm in the previous 42 months), for example, is $8.2 \%$ for Ireland and $5.7 \%$ for Wales (Table 2). If entrepreneurship is classified by sector, the rate of Total Early Stage Entrepreneurial Activity classified as high technology knowledge intensive averages $0.9 \%$ in Ireland, compared to $0.3 \%$ in Wales. That is, in Ireland the rate is three times higher than the rate reported for Wales. The difference between Ireland and Wales is smaller when we use the broader classification of knowledge intensive sectors, the rate of Total Early Stage Entrepreneurial Activity in Ireland is 3.2\%, compared to $2.6 \%$ in Wales. In terms of a narrower classification of entrepreneurship, New Firm Activity (i.e., those that have started a new firm in the previous 42 months) there is a larger difference between Ireland and Wales when New Firm Activity is classified into sectors. Rates of New Firm Activity in the high and medium technology manufacturing sector are $3.1 \%$ in Ireland compared to $0.6 \%$ in Wales.

Table 2 Early stage entrepreneurial activity and components for Ireland and Wales, 2003 to 2006 (average)

\begin{tabular}{lcc}
\hline & Ireland & Wales \\
\hline Nascent entrepreneurial activity & $4.9 \%$ & $3.1 \%$ \\
New firm activity & $3.8 \%$ & $2.9 \%$ \\
Total early stage entrepreneurial activity & $8.2 \%$ & $5.7 \%$ \\
Knowledge Intensive total early stage entrepreneurial activity $^{1}$ & $3.2 \%$ & $2.4 \%$ \\
High tech knowledge intensive total early stage entrepreneurial activity $^{2}$ & $0.9 \%$ & $0.3 \%$ \\
\hline
\end{tabular}

Notes: 1 includes only those early stage entrepreneurs classed as knowledge intensive

2 includes only those early stage entrepreneurs who operate in high technology, or medium high technology manufacturing sectors, or the high technology knowledge intensive service sectors.

Source: Global Entrepreneurship Monitor Data, 2003 to 2006 
Table 3 Age of early stage entrepreneurs by sector knowledge intensity, 2003 to 2006

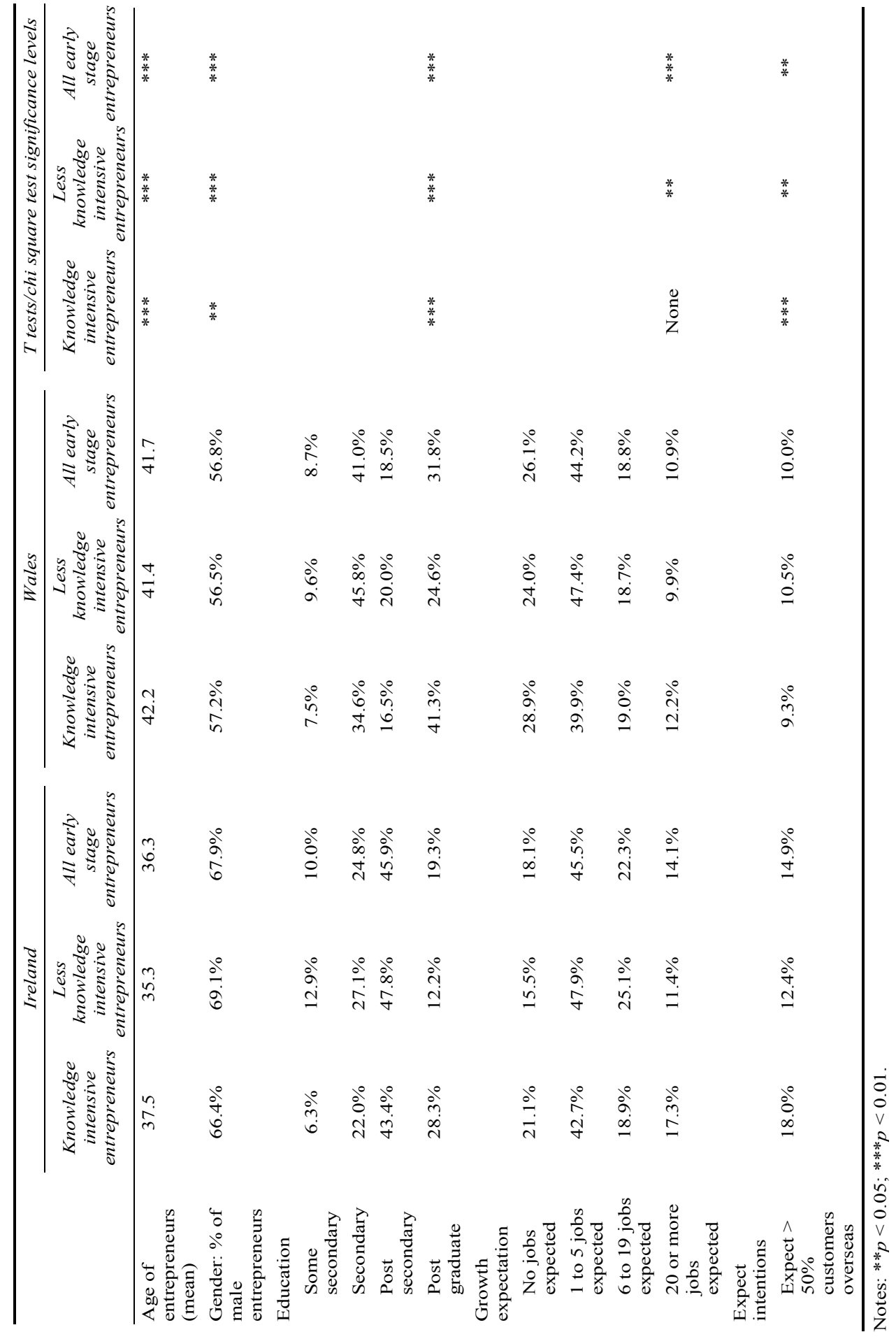


Exploring the characteristics of entrepreneurs in Ireland and Wales, we identify a number of differences (Table 3). These differences apply to entrepreneurs in Ireland and Wales in general and also specifically to knowledge-based entrepreneurs. Irish knowledge-based entrepreneurs are younger, more likely to be male, more educated (combining post secondary and post graduate categories), and more export oriented, when compared to knowledge-based entrepreneurs in Wales.

\subsection{Policy in Ireland and Wales}

The data presented above suggests that both Ireland and Wales failed to develop an indigenous knowledge creating capacity. In response to this both regions actively pursued policies aimed at attracting FDI. However, the nature and extent of FDI evolved differently in Ireland and Wales. In addition, the extent and nature of knowledge intensive entrepreneurship also differs between the two regions. We now describe policy in Ireland and Wales to explore if, and how, policies shaped the nature and extent of FDI, and to explore if and how policies sought to exploit knowledge spillovers and increase levels of knowledge -based entrepreneurship.

\subsection{Ireland: FDI and entrepreneurship development policy}

Ireland's economic success during the 1980s and 1990s was partially the result of four decades of pursuing an export led industrial policy that relied on attracting inward FDI. By the end of the 1990s Ireland had the status of a world leader in 'high tech' business activity, with $46.5 \%$ of value added in manufacturing from high technology companies (OECD, 1998); compared with 10\% for the European Union and 16.4\% for the USA. Ireland first started attracting export oriented FDI inflows with the introduction, in the mid 1950s, of a fifteen year 'tax holiday' on profits from export sales3. At the time the Irish government funded the state development agency's programs that built 'advanced factories' (purpose built factory accommodation for overseas firms) and provided generous capital grants to foreign firms.

Such initiatives, aided by Ireland's entry into the European Economic Community in 1973, led to significant success in attracting inward FDI during the period from 1973 to 1980 (Ruane and Grög, 1996). However, the oil shocks of the 1970s and ensuing global recession forced many foreign firms to close their operations in Ireland. In particular, labour intensive firms involved in sectors such as man made fibres, textiles, clothing and footwear determined that Ireland was no longer an attractive location (Acs et al., 2007).

In response, Ireland's Industrial Development Authority (IDA) developed new policies that targeted 'flagship' emerging high technology sectors such as electronics, computer software, biotechnology and healthcare. Often, the IDA focused on relatively young firms in these new key sectors. The Irish government subsequently extended incentives to cover firms engaged in internationally traded services (e.g., financial services, call centres). Reflecting the nature of such activities and the policy objective of generating employment, firms received employment grants as well as capital grants (that is, payments per job created). In addition, a broad range of policy tools such as training grants, subsidised rents, technology transfer grants and low interest loans were used by the IDA to tailor packages that would be attractive to specific firm needs (Murphy and Ruane, 2004). The Irish Government also sought to increase the flow of trained graduates to industry by creating new National Institutes of Higher Education (tertiary colleges with 
a focus on vocational skills). From the 1990s, the number of firms investing in Ireland increased significantly. In particular, there was a tremendous growth in the scale of FDI inflows from the USA, and a growing proportion of FDI was directed to ICT sectors.

Ireland's success at attracting FDI also broadly reflects government commitment to the policy objective, government policy initiatives and instruments, and the IDA's extensive efforts. These policies evolved over time, as has the rationale for why firms elected to establish operations in Ireland (Begley et al., 2005). The key reasons why firms have chosen to locate in Ireland more recently include the following: low corporate tax regime, access to capital and employment grants, IDA lobbying, a pro business regulatory environment and government, 'demonstration effects' and the availability, at a low cost, of a young, English speaking, educated and trained workforce. Reviewing the effectiveness of policies aimed at attracting FDI, Murphy and Ruane (2004, p.135) argued that three factors partly explain Ireland's success:

a the emergence of self sustaining clusters in area such as software, electronics, pharmaceuticals and financial services that resulted from the targeted approach of the IDA and efforts to build vertical linkages

b the extension of incentives to include internationally traded services

c the emergence of a pro FDI reputation, that reflects the consistency and pro active nature of Irish government policies towards FDI.

In addition to attracting inward FDI, however, Irish industrial policy has also sought to support export oriented indigenous firms, including new enterprises, highlighting a consistent focus for FDI and entrepreneurship policies conducted simultaneously, evidence suggesting that the performance of indigenous manufacturing firms has improved. Today's indigenous manufacturing firms, for example, are more export oriented and profitable than those operating before 1987 (O'Malley, 2004). Industrial policy focused assistance on established and new manufacturing firms which had potential to either export or to substitute for an imported product.

As such Irish entrepreneurship policy focused on a narrow range of 'high potential start up' ventures, mainly manufacturing firms with export potential and 'internationally traded services' businesses. The range of measures used to assist established and new manufacturing firms includes preferential corporate tax 4 and capital and employment grants. For example, as long ago as 1978, the IDA initiated the enterprise development programme (EDP) that targeted managers, professionals (engineers and accountants) and academics to start businesses with high growth potential. Often the new EDP ventures supplied to foreign owned firms or import substitution businesses. EDP entrepreneurs received extensive state assistance in terms of loan guarantees and 'soft support'. Over the 20 years the EDP operated, about 350 businesses received state assistance, across sectors such as machinery/tool making/computers, electrical and electronics, food, instruments and medical devices and internationally traded services. The IDA also operated a 'Linkages Programme' under which it actively sought to encourage established and new firms to exploit sub supply opportunities with foreign firms. This programme enjoyed moderate success in some sectors, such as electronics, although the nature of foreign firm activity required that a significant proportion of exports consist of components sourced from outside Ireland.

Current supports for entrepreneurial activity are also focused on a small number of new start ups engaged in manufacturing or internationally traded services (for example 
software firms) and are delivered by Enterprise Ireland, the sister organisation of IDA5. Enterprise Ireland provided assistance to 54 high potential start ups (HPSUs) in 2002 and 65 HPSUs in 2004. Policy interventions by Enterprise Ireland have evolved to include initiatives aimed at stimulating venture capital investments (by part investing in venture capital funds) and funding university and institute incubators. In addition, regional County Enterprise Boards were introduced to support and promote entrepreneurial activity in a broader range of sectors, although they also act as the 'seed' development stage for future Enterprise Ireland clients.

\subsection{Wales: FDI and entrepreneurship development policy}

Historically the Welsh economy has been biased towards the heavy industries of coal and steel. The decline of these industries in the 1970s and 1980s led to high unemployment levels in Wales in the 1980s (National Audit Office, 1990). The Welsh Office and Welsh Development Agency (WDA) therefore placed great importance on tackling unemployment and creating and safeguarding jobs in Wales. One way of achieving this was attracting inward FDI. During the 1980s the WDA was successful at attracting inward FDI, with Wales securing a disproportionate percentage of inward FDI into the UK, approaching $20 \%$ of the UK total in some years whereas Wales accounted for under $5 \%$ of the UK population (see Hill and Munday, 1992). The WDA was particularly successful at attracting FDI in the electronics, automotive equipment and transport equipment sectors.

In pursuing this policy, the WDA was able to assist FDI in accessing UK Government schemes such as the regional development grant (RDG) and RSA programmes, and more recently to significant EU funds, between 1990 and 1997 receiving $£ 890 \mathrm{~m}$ in regional preferential assistance (RPA) to industry, a third of the UK total and a quarter of UK RSA spending (Brooksbank et al., 2001). Unsurprisingly, research focused on the association among these relatively high levels of RPA to industry in Wales, infrastructure development and the disproportionately high share of inward investment that the region has received (Hill and Munday 1992; Jones, 1996). More specifically the reasons for the WDA's success at attracting inward FDI include the presence of the following: grant assisted areas close to the rich markets of the South East of England, a plentiful, and cheap, source of semi skilled labour, and good road infrastructure (Munday and Roberts, 2001).

In 1998, however, there was a change in focus for RSA, with the Department of Trade and Industry stating that the RSAs would now focus support on high quality, knowledge -based projects that provided skilled jobs. However, there is evidence to suggest that, following these changes, the key reasons for foreign firms already located in Wales investing more into their existing plants were still predominantly linked to labour skills and costs and government assistance, with only a minor role for local suppliers, partnerships and training, and virtually no impact from local technology transfer activities or links with local research institutions (Phelps et al., 2003). The lack of a strong indigenous entrepreneurial business base (not least because of the concentration in coal and steel) led to a reliance on public sector investment in the long declining coal and steel industries and attraction of manufacturing investment from foreign owned multinationals, often in relatively low skilled areas. Morgan (1997) argues that it was only when the foreign inward investment began to become more difficult to attract in the early to mid 
1990s that policy began to focus more heavily on business support, technology transfer, skills development and indigenous entrepreneurship.

Since 1998, the Welsh policy focus has therefore shifted from attracting FDI towards a focus on indigenous firm growth. This coincided with a fall in FDI flows, political devolution, European Union Objective One funding for two thirds of Wales and a new economic development strategy (NEDS) for Wales including for the first time, an Entrepreneurship Action Plan. The enterprise policy focussed on the growth of small Welsh businesses and raising entrepreneurship in general, rather than on a more specific policy related to knowledge-based entrepreneurship (Entrepreneurship Action Plan, 2000). Explicit aims were to:

1 create an entrepreneurial culture where more people recognise business opportunities and are motivated and skilled to convert these ideas into action

2 improve the quality, accessibility and relevance of advice and training infrastructure

3 commit to entrepreneurship by the public sector by supporting small businesses and creating opportunities for local businesses

4 develop an effective implementation plan that cuts across traditional functional boundaries and involves a wide range of organisations.

Wales' focus on knowledge related sectors has, perhaps consequentially, been largely indirect, or relatively modest, with much greater attention given to general entrepreneurship and promotion activities, as well as specific policies aimed at increasing entrepreneurship amongst under represented groups, such as females. Recent policies on entrepreneurship in high growth businesses offered $£ 15 \mathrm{M}$ to support 200 firms through the Entrepreneurship Action plan. The Knowledge Bank for Wales provided an additional $£ 14 \mathrm{M}$ to support high growth potential firms (Welsh Assembly Government, 2005), though many of those assisted initially were larger established firms. Where specific knowledge related activities have been promoted, these tend to focus more on higher education than on FDI. Swansea University's 'technium' network of business incubator accommodation for science and technology businesses, for example was helping generate a distinct sub regional innovation system in South West Wales, incorporating many features identified as critical to successful localised collective learning and innovation. Their effectiveness has been questioned by others, however, (e.g., Cooke, 2003), due to the shortage of academic entrepreneurs relative to the number of new businesses.

\section{Analysis: knowledge spillovers from FDI and knowledge-based entrepreneurship in Ireland and Wales}

The cases presented above illustrate that both Ireland and Wales have been characterised by relatively weak indigenous knowledge creating capacity (as represented by their R\&D spend relative to the OECD average), and that both Ireland and Wales have been relatively (compared with their population sizes) successful in attracting inward FDI, though importantly they have diverged in recent years in terms of the nature and scale of FDI. While there are on going concerns in both Ireland and Wales about the embeddedness of foreign firms, the presence of strategic functions, and closure and relocation of firms to lower cost locations, it is evident (Table 4) that FDI in Ireland has 
included a significant amount of investment in business services, that there has been a shift towards FDI in high technology sectors, and that FDI in Ireland increasingly employed higher educated workers. This suggests that FDI in Ireland has changed in a way that makes it more knowledge intense and therefore there may be a greater potential for knowledge spillovers. FDI in Ireland may have created entrepreneurial opportunities. In contrast we do not observe evidence of such changes in Wales.

Table 4 Distribution of early stage entrepreneurial activity (2003 to 2006) and FDI (Ireland 1998 to 2002; Wales 1990 to 1999 ) by sector

\begin{tabular}{|c|c|c|c|c|}
\hline & $\begin{array}{c}\text { Ireland: } \\
\text { early stage } \\
\text { entrepreneurship } \\
(n=470)\end{array}$ & $\begin{array}{l}\text { Ireland: } \\
\text { FDI }\end{array}$ & $\begin{array}{c}\text { Wales: } \\
\text { early stage } \\
\text { entrepreneurship } \\
(n=910)\end{array}$ & $\begin{array}{l}\text { Wales: } \\
\text { FDI }\end{array}$ \\
\hline Total manufacturing & $8.5 \%$ & $53.0 \%$ & $6.6 \%$ & $94.5 \%$ \\
\hline Food & $0.6 \%$ & $4.0 \%$ & $0.8 \%$ & $3.3 \%$ \\
\hline Textiles & $0.2 \%$ & $0.001 \%$ & $1.1 \%$ & $0.6 \%$ \\
\hline Wood/paper and publishing & $2.3 \%$ & $0.001 \%$ & $1.8 \%$ & $6.6 \%$ \\
\hline Fuels and man made fibres & $0.0 \%$ & $20.0 \%$ & $0.2 \%$ & $12.1 \%$ \\
\hline Minerals & $0.9 \%$ & $1.0 \%$ & $0.1 \%$ & $2.5 \%$ \\
\hline Metals & $0.2 \%$ & $0.5 \%$ & $0.4 \%$ & $11.1 \%$ \\
\hline Equipment & $1.1 \%$ & $10.0 \%$ & $0.1 \%$ & $1.1 \%$ \\
\hline Radio, TV and electrical goods & $1.5 \%$ & $15.0 \%$ & $0.1 \%$ & $39.6 \%$ \\
\hline Vehicles & $0.0 \%$ & $0.5 \%$ & $0.7 \%$ & $15.7 \%$ \\
\hline Other & $1.7 \%$ & $2.0 \%$ & $1.3 \%$ & $1.9 \%$ \\
\hline Agriculture & $5.5 \%$ & $0.001 \%$ & $4.7 \%$ & $0.0 \%$ \\
\hline Mining & $0.6 \%$ & $0.001 \%$ & $0.3 \%$ & $0.01 \%$ \\
\hline $\begin{array}{l}\text { Wholesale, retail, repair of motor } \\
\text { vehicles }\end{array}$ & $13.2 \%$ & $8.0 \%$ & $14.5 \%$ & $2.8 \%$ \\
\hline Construction & $13.2 \%$ & $1.0 \%$ & $13.4 \%$ & $0.1 \%$ \\
\hline Hotels and restaurants & $5.5 \%$ & $0.010 \%$ & $7.5 \%$ & $0.0 \%$ \\
\hline Transport, storage and post & $6.6 \%$ & $10.0 \%$ & $4.4 \%$ & $0.0 \%$ \\
\hline Real estate and business services & $28.5 \%$ & $22.0 \%$ & $26.0 \%$ & $2.4 \%$ \\
\hline Electricity, gas and water supply & $0.9 \%$ & $4.0 \%$ & $0.3 \%$ & $0.0 \%$ \\
\hline Education, health and water & $6.6 \%$ & $0.001 \%$ & $10.8 \%$ & $0.0 \%$ \\
\hline Other sectors & $10.9 \%$ & $0.0 \%$ & $11.4 \%$ & $0.0 \%$ \\
\hline
\end{tabular}

Source: Ireland figures based on UNCTAD (2005); OECD (2005); Wales

figures based on RSA data; * includes high technology

While the entrepreneurial opportunities potentially created by inward FDI will be a narrow subset of all entrepreneurial opportunities in an economy it is also illustrative to compare the nature of early stage entrepreneurial activity for the period 2003 to 2006 to the sector distribution of FDI for Ireland and Wales This comparison illustrates that there may be links between FDI and the nature of subsequent entrepreneurial activity. This seems particularly the case for the industries classed as knowledge intensive (Eurostat definition) which are found predominantly in manufacture of equipment, 
electrical goods, vehicles, other manufacturing, transport and storage and business services. In these areas Ireland and Wales both have concentrations of FDI activity $(59.5 \%$ and $60.5 \%$ respectively). In Wales, however, FDI is concentrated in manufacturing, whereas early stage entrepreneurship has been in services. In Ireland there has been a closer relationship between the location of knowledge intensive related FDI and early stage entrepreneurial activity. This is particularly true for high technology, knowledge-based entrepreneurship (both manufacturing and services), as is also shown in Table 4.

While the effects of knowledge spillovers from MNEs into the local economy can be difficult to analyse specifically, Grög and Strobl (2002) demonstrate that the presence of MNEs has a positive effect on the entry of indigenous manufacturing firms in industries in Ireland. They conclude that this effect reflects both the presence of MNEs in the same industry and the presence of MNEs in downstream industries. There is a positive indirect employment effect of MNEs on locally-based suppliers, including both indigenous and foreign owned suppliers, in the Irish electronics sector (Grög and Ruane, 2001). Furthermore, of the 270 new high potential start ups that received assistance from Enterprise Ireland between 1999 and 2003, 88 (33\%) were started by entrepreneurs whose immediate prior place of employment was a foreign multinational firm in Ireland; while $27(10 \%)$ were started by entrepreneurs leaving universities and institutes. In particular, the presence of MNEs seems to have stimulated indigenous investment and new companies in the same industries, but in different product categories. Foreign firms significantly and positively influenced the emergence of strong competitive advantage in indigenous software firms in the Irish software sector (O'Malley and O'Gorman, 2001). These benefits include the development of a skilled workforce, access to market opportunities and, in particular, export markets. Indigenous firms also benefit from investments in the tertiary education system that sought to produce graduates with skills suitable to attracting FDI (Acs et al., 2007). In addition, 'on the job' learning in MNEs in a broad range of sectors is important in developing the skills of the indigenous firms' workforce. Also in some sectors populated by foreign owned firms, there is also a direct increase in indigenous entrepreneurial activity. The most striking example can be found in the software sector in which both indigenous companies and Irish subsidiaries of MNEs achieved worldwide success.

In contrast, the 'low skill' nature of foreign firm activity in Wales may have had deleterious effects on SME development, and knowledge-based entrepreneurship in particular. The shortage of skilled jobs may force potential employees to leave a region, thus reducing the pool of potential entrepreneurs and innovators (Firn, 1975). Phelps et al. (2003) suggests only minimal local links in higher functional areas related to innovation in Wales in the pre 2003 period, though they also highlight that more focused recent initiatives targeted at a small number of inward investors may improve this situation. The Source Wales initiative to improve local supply linkages did not have time to dramatically impact the situation, with only a quarter of the plants having had links with this initiative (Phelps et al., 2003). Overall, as institutional initiatives develop, there is a better balance between inward investment and indigenous development, further emphasising the relatively recent nature of initiatives to link the two (Phelps et al., 2003).

Prior to the end of the FDI boom at the end of the 1990s, Wales began to generate a 'regional innovation system' (Cooke et al., 2003). With greater supply chain integration and innovative cluster interactions in electronics and automotive components as 
multinationals became more locally embedded, often with assistance from public subsidies (Cooke, 2003). This was not, however, integrated with a specific policy of enterprise development. FDI in Wales was relatively innovative, and thus its declining presence weakened regional innovation in Wales generally, including that from SMEs in the supply chain (Cooke, 2003). Phelps et al. (2003) also report that whilst $70 \%$ of foreign investors have some links with local training providers, this tended to be at the level of school and Training and Enterprise councils, with only $7.7 \%$ making use of relevant degree schemes, again emphasising the relatively low level of the skills requirements.

\section{Discussion}

As stated earlier, the knowledge spillover theory of entrepreneurship highlights that low levels of knowledge -based entrepreneurship can result from:

1 failure of private firms and public institutions to generate new knowledge (in which FDI can be seen as playing a knowledge providing role)

2 failure of individuals to exploit that new knowledge (through entrepreneurship).

In such contexts policymakers might pursue inward FDI as a means of increasing the knowledge base and increasing the technology and skills used in indigenous industry. The two case histories outlined here, of policy in Ireland and Wales, suggest that the experiences in Ireland and Wales are broadly consistent with the knowledge spillover theory of entrepreneurship (Table 5).

The different policy foci in Ireland and Wales potentially provide at least a partial explanation for the differences in levels of knowledge intensive entrepreneurship. Whilst the differences in entrepreneurship in Ireland and Wales may also reflect differences in the institutional contexts in the two case countries, the knowledge spillover theory of entrepreneurship focuses attention on entrepreneurial opportunity, and suggests how FDI can lead to increased knowledge-based entrepreneurship. The case evidence suggests that policy efforts in Ireland that influenced the nature of inward FDI may have increased the knowledge intensity of subsidiaries, increasing the potential for knowledge spillovers. While investigating domestic barriers to entrepreneurship falls outside the scope of this paper, we do highlight that in Ireland entrepreneurship policies directly sought to exploit the presence of FDI. In Ireland, therefore, there has been a concerted, consistent and simultaneous focus in both FDI and entrepreneurship development in complementary areas over the last two decades, related to export led and knowledge intensive sectors. Irish entrepreneurship policy focuses more narrowly on 'high potential start ups.' Irish entrepreneurs who received support tended to be well educated and to start businesses in knowledge-based sectors such as software. Ireland's science and technology development policy specifically includes an integration of high technology foreign firms into the economy, with development of high technology indigenous firms, through attraction of high level foreign firm functions, but also by developing the innovation capability of indigenous firms to access, assimilate, absorb and adapt new technologies (Jones-Evans, 2002). 
Table 5 Entrepreneurship and FDI: Ireland and Wales

\begin{tabular}{lcc}
\hline & Ireland & Wales \\
\hline $\begin{array}{l}\text { Indigenous knowledge creation capacity } \\
(1980 \text { s 2000s) }\end{array}$ & & Low \\
R\&D expenditure & Low & \\
FDI inflows & & High though higher \\
Up to 1998: FDI inflows & $\begin{array}{c}\text { High, though lower } \\
\text { than in Ireland }\end{array}$ \\
than in Wales & High, and a rapid & High, but declining \\
Post 1998: FDI inflows & increase & inflows \\
& & \\
FDI inflows by sector (1980 \& 1990s) & $53 \%$ & $94 \%$ \\
Total manufacturing & $22 \%$ & $2 \%$ \\
Real estate and business services & $8 \%$ & $3 \%$ \\
Wholesale, retail, repair of motor vehicles & $17 \%$ & $1 \%$ \\
Other & $100 \%$ & $100 \%$ \\
& Ireland v Wales & Wales v Ireland \\
Entrepreneurship (2003 to 2006) & Higher & Lower \\
Total early stage entrepreneurial activity & Higher & Lower \\
High technology knowledge intensive total & & Lower \\
early stage entrepreneurial activity & Higher & \\
High and medium technology new firm & & \\
activity & &
\end{tabular}

In contrast, Jones-Evans (2002) criticises the lack of such a coherent science and technology policy for Wales. Instead, Wales targeted raising entrepreneurship levels more generally following the FDI attraction focus of the 1980s and 1990s. Wales, unlike Ireland, did not pursue a linked and simultaneous strategy of FDI and entrepreneurship. Rather, until the late 1990s, Wales focused on FDI which assisted in the development of a FDI focused regional innovation system (Cooke, 2003). Wales' attention to entrepreneurship emerged more recently and there have been comparatively few attempts to link the two until relatively recently.

Practically this may be a result of issues over resources. In Wales, the resources obtained by FDI on an ongoing basis may have reduced the resources available for entrepreneurship policy (Brooksbank and Pickernell, 2001). Cooke (2003) also concludes that the Welsh Assembly Government's attempts to develop the Welsh 'regional innovation system' in the absence of large scale FDI may have failed to foster entrepreneurship and innovation because of risk aversion, tight central control of budgets, and enterprise and innovation support instruments designed for public rather than private benefit. Welsh entrepreneurship priorities were also broader, with a focus on overall entrepreneurial activity and ultimately less policy resource on high growth early stage entrepreneurship than originally planned.

The case evidence suggests that the extent and nature of FDI matters to the likelihood of knowledge spillovers occurring. However, the policy evidence from Ireland and Wales suggests that the policy in both regions emerged over time and that there was a strong 'path dependency' in the policy choices observed in Ireland but not in Wales. So 'knowing' the types of firm that might lead to spillovers is not what which differentiated 
the two regions, but rather it was that FDI policy choices over time created different opportunities from FDI in the two regions. Also, efforts to maximise the impact of FDI appear to need deliberate and targeted entrepreneurship policy choices, suggesting that more general entrepreneurship policies aimed at creating an environment conducive to entrepreneurship may provide necessary but not sufficient conditions for the emergence of knowledge intensive entrepreneurship.

\section{Conclusions}

Policymakers seeking to facilitate and encourage knowledge intensive entrepreneurship can pursue a diverse range of initiatives, investment and policies such as creating the institutions that support regions characterised by high levels of knowledge intensive entrepreneurship. In this paper we used the knowledge spillover theory of entrepreneurship to explore how policies aimed at FDI may or may not lead to knowledge intensive entrepreneurship. The knowledge spillover theory of entrepreneurship focuses the attention of policymakers on how the knowledge (created) in organisations (such as universities and firms) can lead to entrepreneurial opportunities for others.

We sought evidence to support the theory's applicability within the context of Ireland and Wales, focusing on identifying if, and how, FDI policies might be associated with increased levels of knowledge intensive entrepreneurship. While we focus on how one common policy approach, the attraction of inward FDI, might create entrepreneurial opportunity, we cannot discount other explanations for the emergence of knowledge intensive entrepreneurship. What we observe in Ireland and Wales is that in recent decades they have both been characterised by weak knowledge creating capacity. The two countries' lagged economic development led to proactive policies to attract inward FDI. Using the GEM dataset we identified differences between Ireland and Wales in terms of the nature and scope of entrepreneurial activity. Specifically, we identified a higher level of high technology manufacturing entrepreneurship in Ireland compared to Wales, and that these entrepreneurs in Ireland are more growth and export orientated.

Does the knowledge spillover theory of entrepreneurship, as related to FDI and entrepreneurship policies, provide at least a partial explanation for the greater emergence of knowledge-based entrepreneurship in Ireland compared with Wales? The cases suggest that, for policy related reasons, FDI in Ireland assisted the emergence of high technology entrepreneurship to a much greater extent than has been the case in Wales. The GEM data indicates, broadly, that Ireland has a more robust entrepreneurial sector than does Wales and crucially it also appears that Ireland invoked policies to both encourage and to take advantage of knowledge spillovers from FDI, (for example, in the software industry), to a greater and more coordinated extent than has occurred in Wales. In Ireland, policies directed at attracting inward FDI were also linked over a longer time period to those focused on indigenous entrepreneurial activity, seeking therefore to maximise the benefits of inward FDI on indigenous industry. In contrast, Wales does not appear to have taken full advantage of FDI, partly as a result of an original policy focus more related to job creation in deprived areas.

Attracting FDI has become much more competitive (with the expansion of the EU into central and Eastern Europe and the 'opening up' of China). Our data suggests that Wales requires much more focused FDI attraction/utilisation polices that have greater potential to lead to spillovers that local entrepreneurs can exploit. This will also, of 
course, require entrepreneurship policies that encourage entrepreneurial activity (in high potential, high growth areas) among those with the resources and knowledge to exploit such knowledge spillovers. Crucially, of course, this will require that these policies are integrated both with each other and with science and technology policy more generally to increase levels of knowledge creation and utilisation.

In order to more fully evaluate the relationships between FDI policies and entrepreneurship policies and their impact on knowledge intensive entrepreneurship, the future evidence base needs to be stronger, particularly in terms of more quantitative analysis of the relationships described here. Greater testing of emerging theory on the linkages between knowledge spillovers, entrepreneurship theory, FDI and regional policy in advanced economies is also needed to make a clearer distinction between developed and developing country contexts (Blomstrom and Kokko, 2003).

More generally, however, our analysis suggests that policy choices matter and that countries characterised by weak indigenous knowledge creating regimes can at least partially compensate by attracting inward FDI and that, depending on the nature of this FDI and the nature of supporting entrepreneurship policies, knowledge spillovers may lead to an increase in knowledge-based entrepreneurship.

\section{References}

Acemoglu, C., Johnson, S. and Robinson, J. (2004) 'Institutions as the fundamental cause of long run growth', in Aghion, P. and Durlauf, S. (Eds.): Handbook of Economic Growth, Vol. 1, Chapter 6, pp.405-472, Elsevier North Holland, New York.

Acs, Z., Arenius, P., Hay, M. and Minniti, M. (2004) Global Entrepreneurship Monitor: 2004 Executive Report, Babson College and London Business School.

Acs, Z., O'Gorman, C., Szerb, L. and Terjesen, S. (2007) 'Could the Irish miracle be repeated in Hungary', Small Business Economics, Vol. 28, Nos. 2/3, pp.123-142.

Amin, A. and Tomaney, J. (1998) 'The regional development potential of inward investment', in Storper, M., Thomadakis, S.B. and Tsipouri, L.J. (Eds.): Latecomers in the Global Economy, Routledge, London and New York.

Arrow, k. (1962) 'Economic welfare and the allocation of resources for invention', in R. Nelson (Ed.): The Rate and Direction of Inventive Activity, pp.609-626, Princeton University Press, NJ, NBER.

Audretsch, D. and Keilbach, M. (2004) 'Entrepreneurship and regional growth: an evolutionary interpretation', Journal of Evolutionary Interpretation, Vol. 14, No. 5, pp.606-616.

Audretsch, D. and Keilbach, M. (2007) 'The theory of knowledge spillover entrepreneurship', Journal of Management Studies, Vol. 44, No. 7, pp.1242-1254.

Audretsch, D., Carree, M., van Stel, A. and Thurik, R. (2002) 'Impeded industrial restructuring: the growth penalty', Kyklos, Vol. 55, No. 1, pp.81-98.

Audretsch, D.B. and Lehmann, E.E. (2005) 'Does the knowledge spillover theory of entrepreneurship hold for regions?', Research Policy, Vol. 34, No. 8, pp.1191-1202.

Autio, E. and Acs, Z.J. (2010) 'Intellectual property protection and the formation of entrepreneurial growth aspirations', Strategic Entrepreneurship Journal, Vol. 4, No. 3, pp.234-251.

Baumol, W. (1993) Entrepreneurship, Management, and the Structure of Payoffs, MIT Press, Cambridge, MA.

Begley, T., Delaney, E. and O'Gorman, C. (2005) 'Ireland at the crossroads: still a magnet for corporate investment', Organizational Dynamics, Vol. 34, No. 3, pp.202-217.

Blomström, M. and Kokko, A. (2003) 'The economics of foreign investment incentives', CEPR, February, Working paper. 
Braunerhjelm, P., Acs, Z., Audretsch, D. and Carlsson, B. (2010) 'The missing link: knowledge diffusion and entrepreneurship in endogenous growth', Small Business Economics, Vol. 34, No. 2, pp.105-125.

Brooksbank, D. and Pickernell, D. (2001) 'Changing the name of the game? RSA, indigenous and inward investors, and the national assembly for Wales', Regional Studies, Vol. 35, No. 3, pp.271-277.

Brooksbank, D., Clifton, N., Jones Evans, D. and Pickernell, D. (2001) 'The end of the beginning? Welsh regional policy and objective one', European Planning Studies, Vol. 9, No. 2, pp.255-274.

Carree, M., van Stel, A., Thurk, R. and Wennekers, S. (2002) 'Economic development and business ownership: an analysis using data of 23 OECD countries in the period of 1976-1996', Small Business Economics, Vol. 19, No. 3, pp.271-290.

Chandler, A. (1990) Scale and Scope: The Dynamics of Industrial Capitalism, Belknap Press, London, Cambridge, Mass.

Clifton, N., Pickernell, D. and Khan, Z. (2000) 'The Welsh first tier automotive industry and new product development', Welsh Economic Review, Vol. 12, No. 1, pp.24-28.

Coe, N. (1997) 'US transnationals and the Irish software industry: assessing the nature, quality and stability of a new wave of foreign direct investment', European Urban and Regional Studies, Vol. 4, No. 3, pp.211-230.

Cooke, P. (2003) 'The regional innovation system in Wales: evolution or eclipse', in Cooke, P. Heidenreich, M. and Braczyk, H. (Eds.): Regional Innovation Systems, 2nd ed., Routledge, London.

Cooke, P., Roper, S. and Wylie, P. (2003) 'The 'golden thread of innovation' and Northern Ireland's evolving regional innovation system', Regional Studies, Vol. 37, No. 4, pp.365-380.

CSO (1992) Census of Production 1992 PA1002, CSO, London.

Davidsson, P. and Henrekson, M. (2002) 'Determinants of the prevalence of start-ups and high growth firms', Small Business Economics, Vol. 19, No. 2, pp.81-94.

Entrepreneurship Action Plan (2000) The Entrepreneurship Action Plan for Wales: Making it Happen, Implementation Plan, Welsh Assembly Government, Cardiff.

Firn, J. (1975) 'External control and regional development: the case of Scotland', Environment \& Planning A, Vol. 7, No. 4, pp.393-414.

Grög, H. and Ruane, F. (2001) 'MNCs and linkages: panel data evidence from the Irish electronics industry', International Journal of the Economics of Business, Vol. 8, No. 1, pp.1-18.

Grög, H. and Strobl, E. (2002) 'Multinational companies and indigenous development: an empirical analysis', European Economic Review, Vol. 46, No. 5, pp.1305-1322.

Hill, S. and Munday, M. (1992) 'The UK regional distribution of foreign direct investment: analysis and determinants', Regional Studies, Vol. 26, No. 6, pp.535-544.

Johnson, P. (2004) 'Differences in regional firm formation rates: a decomposition analysis', Entrepreneurship Theory \& Practice, Vol. 28, No. 5, pp.431-445.

Jones, G. (1996) Wales 2010: Three Years On, Institute of Welsh Affairs, Cardiff.

Jones, J. and Wren, C. (2002) Inward Investment and the Regional Economy, unpublished manuscript.

Jones-Evans, D. (2002) Research and Development in Wales, Research Paper delivered to the Economic Development Committee, National Assembly for Wales, Cardiff.

Kraus, S. (2011) 'State-of-the-art current research in international entrepreneurship: a citation analysis', African Journal of Business Management, Vol. 5, No. 3, pp.1020-1038.

Kuemmerle, W. (1999) 'The drivers of foreign direct investment into research and development: an empirical investigation', Journal of International Business Studies, Vol. 30, No. 1, pp.1-24.

Levie, J. and Autio, E. (2008) 'A theoretical grounding and test of the GEM model', Small Business Economics, Vol. 31, No. 3, pp.235-264. 
Liu, Z. (2002) 'FDI and technology spillover: evidence from China', Journal of Comparative Economics, Vol. 30, No. 3, pp.579-602.

Morck, R. and Yeung, B. (1992) 'Internalization: an event study test', Journal of International Economics, Vol. 33, No. 1, pp.41-56.

Morgan, K. (1991) 'Competition and collaboration in the electronics industry: what are the prospects for Britain?', Environment and Planning, Vol. 23, No. 5, pp.1459-1482.

Morgan, K. (1997) 'The learning region: institutions, innovation and regional renewal', Regional Studies, Vol. 31, No. 5, pp.491-503.

Mueller, S. and Thomas, A. (2001) 'Culture and entrepreneurial potential: a nine country study of locus of control and innovativeness', Journal of Business Venturing, Vol. 16, No. 1, pp.51-75.

Munday, M. (1995) 'The regional consequences of the Japanese second wave', Local Economy, Vol. 10, No. 1, pp.4-20.

Munday, M. and Roberts, A. (2001) 'Assessing the regional transactions of foreign manufacturers in Wales: issues and determinants', Tijdschrift voor Economische en Sociale Geografie, Vol. 92, No. 2, pp.202-216.

Murphy, A. and Ruane, F. (2004) FDI in Ireland: An Updated Assessment, Central Bank and Financial Services Authority Annual Report 2003, Dublin, Ireland.

National Audit Office (1990) National Audit Office Survey of Welsh Development Agency investments, (unpublished study).

National Economic and Social Research Council (2003) An Investment in Quality: Services, Inclusion and Enterprise, Government Publications Office, Dublin.

Naveretti, G.B. and Venables, A. (2004) 'FDI and the host economy: a case study of Ireland', in Haaland, J. and Venables, A. (Eds.): Multinational Firms in the World Economy, pp.187-216, Princeton University Press, UK.

O'Malley, E. (2004) 'Competitive performance in Irish industry', Quarterly Economic Commentary, Winter, Vol. 26, No. 3.

O'Malley, E. and O'Gorman, C. (2001) 'Competitive advantage in the Irish indigenous software industry and the role of inward FDI', European Planning Studies, Vol. 9, No. 3, pp.303-321.

OECD (2005) FDI Database, available at http://www.oecd.org/dataoecd/14/3/8264806.xls (accessed on December 2010).

OECD (2006a) Main Science and Technology Indicators, OECD, Paris.

OECD (2006b) Factbook 2006: Economic, Environmental and Social Statistics, OECD, Paris.

Organisation for Economic Cooperation and Development (OECD) (1998) Fostering Entrepreneurship, OECD, Paris.

Oviatt, B. and McDougall, P. (2005) 'Defining international entrepreneurship and modelling the speed of internationalization', Entrepreneurship Theory and Practice, Vol. 29, No. 5, pp.537-554.

Phelps, N., Mackinnon, D., Stone, I. and Braidford, P. (2003) 'Embedding the multinationals? Institutions and the development of overseas manufacturing affiliates in Wales and North East England', Regional Studies, Vol. 37, No. 1, pp.27-40.

Pickernell, D. (1997) 'Less pain but what gain ?: A comparison of the effectiveness and effects of Japanese and non Japanese car assemblers' buyer supplier relations in the UK automotive industry', Omega, Vol. 25, No. 4, pp.377-395.

Pickernell, D. (1999) 'Inward investment, diffusion of knowledge and new working practices', Local Economy, Vol. 14, No. 2, pp.144-160.

Regional Trends (1996) 31, HMSO, London.

Reynolds, P., Storey, D. and Westhead, P. (1994) 'Cross national comparisons of the variation in new firm formation rates', Regional Studies, Vol. 28, No. 4, pp.443-456. 
Reynolds, P.D., Bosma, N., Autio, E., Hunt, S., de Bono, N., Servais, I., Lopez Garcia, P. and Chin, N. (2005) 'Global entrepreneurship monitor: data collection design and implementation 1998 1003', Small Business Economics, Vol. 24, No. 3, pp.205-231.

Roberts, A. (1996) 'The economic impact of foreign manufacturing in Wales', unpublished $\mathrm{PhD}$ thesis, University of Wales College Cardiff, Cardiff.

Romer, P. (1990) 'Endogenous technical change', Journal of Political Economy, Vol. 98, pp.S71-S103.

Ruane, F. and Grög, H. (1996) 'Aspects of foreign direct investment in Irish manufacturing since 1973: policy and performance', Journal of the Statistical and Social Inquiry Society of Ireland, Vol. 27, No. 4, pp.1-51.

Saliola, F. and Zanfei, A. (2009) 'Multinational firms, global value chains and the organization of knowledge transfer', Research Policy, Vol. 38, No. 2, pp.369-381.

Scarpetta, S. (2003) The Sources of Economic Growth in OECD Countries, Organisation for Economic Cooperation and Development, Paris.

Storey, D. (2000) 'Six steps to heaven: evaluating the impact of public policies to support small businesses in developed economics', in Sexton, D. and Landström, H. (Eds.): Blackwell Handbook of Entrepreneurship, pp.176-193, Blackwell, Oxford.

Terjesen, S., Hessels, J. and Li, D. (2011) 'Comparative international entrepreneurship research: a review and research agenda', Academy of Management, San Antonio, TX.

UNCTAD (2005) World Investment Report, Transnational Corporations and the Internationalization of R\&D, United Nations, New York and Geneva.

Welsh Assembly Government (2005) ‘ $£ 14 m$ knowledge bank open for business’, Press release, Welsh Assembly Government, Cardiff, available at

http://www.new.wales.gov.uk/news/archivepress/enterprisepress/einpress2005/707405/?lang= en (accessed on 27 March 2007).

Welsh Office (1997) Digest of Welsh Statistics 1997, Government Statistical Services, Cardiff.

Young, S., Hood, N. and Peters, E. (1994) 'Multinational enterprises and regional economic development', Regional Studies, Vol. 28, No. 7, pp.657-679.

\section{Notes}

1 Early stage entrepreneurship is a measure of nascent firm activity (individuals that have done something about setting-up a business in the last 12 months but had not paid wages for more than three months) and new firm activity (new firms that have paid wages for more than three months but less than 42 months).

2 Unpublished internal IDA data.

3 This was replaced with a 10\% tax on all corporate profits from manufacturing in 1980.

4 Indigenous firms could avail of the $10 \%$ manufacturing corporate tax rate in 1980 . However, this incentive was of less value to indigenous firms as those that did manufacture tended to have low rates of profitability.

5 IDA activities were divided into two separate organisations following a review of industrial policy in 1982 . 